\title{
A MÜSZAKI TUDOMÁNYOS ÜLÉSSZAK TÖRTÉNETÉNEK ÁTTEKINTÉSE
}

\section{THE HISTORY OF THE CONFERENCE OF TECHNICAL SCIENCES}

\author{
Bitay Enikő \\ Erdélyi Múzeum Egyesület Müszaki Tudományok Szakosztálya, Kolozsvár, 400009 \\ Cluj-Napoca, str. Napoca (Jókai u.) 2-4., bitay.eniko@eme.ro
}

\begin{abstract}
Present study aims at describing in depth the establishment of a scientific panel, especially its early years, thus demonstrating that difficulties and obstacles in the start-up phase did not shake our faith that technical intelligentsia living as minorities do need all means of scientific life: from research, professional networks and information exchange to anything that may join technical creators in a single community for the sake of one common goal of technical science.

\section{Összefoglalás}

A jelen írás (tanulmány) egy tudományos fórum kialakulását, főleg a kezdeti időszakát szeretné részletesebben bemutatni, s ezzel érzékeltetni, hogy az indulási nehézségek, akadályok nem törték meg a hitünket abban, hogy a kisebbségben élő müszaki értelmiségnek szüksége van a tudományos élet minden elemére, legyen az kutatás, szakmai kapcsolattartás, tudományterjesztés, bármi, ami a müszaki alkotókat egy közösségbe, egy közös célért összefogja, a műszaki tudományosság jegyében.
\end{abstract}

\section{Előzmények}

Az Erdélyi Múzeum-Egyesület 1990-ben Jenei Dezső nyugalmazott főmérnök kezdeményezésére, az újraalakult EME alapszabályzatában a hagyományos szakosztályok mellé ötödikként beiktatta a Müszaki Tudományok Szakosztályát. Korábban az egyesület müszaki érdeklődésű tagjai a Természettudományok és Matematikai Szakosztályba illeszkedve végezték munkájukat. Az Erdélyi Múzeum-Egyesület Müszaki Tudományok Szakosztálya létrehozását a romániai magyar értelmiség szakmai tagolódásában beállt változások tették szükségessé. Az EME újraalakulásakor, 1990-ben azzal a fő célkitüzéssel jött létre, hogy megfelelő keretet biztosítson az erdélyi magyar müszaki értelmiség szakmai és tudományos tevékenységéhez. A Müszaki Tudományok Szakosztálya az indulás évében 176 tagot számlált és 60 müszaki kutatási témával foglalkozott. 
A tapasztalatok igazolták a mérnökök önállósulási törekvését, az EME a szakosztályokban s kiadványokban további szakmai elkülönülési lehetőségeket biztosított.

A Müszaki Tudományok Szakosztálya elsőrendü feladatának a sajátos érdekeit szem előtt tartó tudománypolitika kidolgozását tekintette a maga szakterületén, valamint az eredmények közzétételét, a szakember-utánpótlásnak, a fiatal kutatók szakmai előrehaladásának a támogatását, a magyar müszaki nyelv müvelését, terjesztését és a müszaki értelmiség összefogását $[1,2]$.

A szakosztály mind a mai napig tudományos üléseket és tudomány-népszerüsítő előadásokat, kiállításokat, emléküléseket rendez, szakmai táborokat szervez, és saját körén belül segíti a szaktudományok szerinti csoportok tudományos tevékenységét, müködését. Munkássága eredményeit az egyesület, illetve a szakosztály tudományos kiadványaiban teszi közzé, terjeszti [3].

A szakosztály kezdetben havonta szervezett tudományos felolvasóüléseket meghívott elöadókkal (kutatók, oktatók és az iparban dolgozó mérnökök), a témák felölelték a különböző müszaki szakterületeket.

\section{Jubileumi tudományos ülésszak (I. Múszaki tudományos ülésszak), 2000}

Tízéves tapasztalat birtokában egyre erősebb igény mutatkozott arra, hogy a havi előadások egy tömörebb szakmai információterjesztési fórummal, egy müszaki tudományos ülésszakkal egészüljenek ki a romániai magyar müszaki alkotók, oktatók, kutatók számára a szakosztály már meglévő jelentős fóruma, a Fiatal müszakiak tudományos ülésszaka mellett, mely ekkor már ötéves múlttal rendelkezett. Az új ülésszak összehívására jó alkalom volt a szakosztály létrejöttének 10. évfordulója.

Ebben az időszakban a Magyar Tudományos Akadémia jelentős szerepet vállalt a határon túli intézmények tudományos törekvéseinek megvalósításában.

„Nemzeti tudomány nincs, de igenis van a tudománynak nemzeti funkciója” - hangsúlyozta Glatz Ferenc, az MTA elnöke [4]. Az ő elnöklete alatt alakult meg az MTA Magyar Tudományosság Külföldön Elnöki Bizottsága (1996). „A Magyar Tudományos Akadémia hagyományosan fontos tudománypolitikai kérdésnek tekinti az egyetemes magyar tudományosság ügyét, a magyar-magyar kapcsolatok épitését, a hazai és a határon túli magyar tudományosság eredményes együttmüködését" - írta bevezető tanulmányában Tarnóczy Mariann, az MTA Magyar Tudományosság Külföldön Elnöki Bizottságának titkára [4].

A 2000. májusi közgyülésén az MTA elfogadta a köztestületbe való jelentkezés körének kiterjesztését a határokon túliakra [5].

Az MTA Magyar Tudományosság Külföldön Elnöki Bizottságának hajdani elnöke, Berényi Dénes akadémikus, az elsők között szorgalmazta, hogy A Magyar Tudomány Napjának ünnepe a határon túlra is kiterjedjen. E felhívás $\mathrm{s}$ a fent említett előzmények eredményeképpen indította el az EME Müszaki Tudományok Szakosztálya 2000-ben a Müszaki tudományos ülésszakot a Magyar Tudományos Akadémia fennállásának 175. évfordulója, $A$ 
Magyar Tudomány Napja, valamint az Erdélyi Múzeum-Egyesület Müszaki Tudományok Szakosztálya megalakulásának 10. évfordulója alkalmából.

Eredeti terveink szerint fórumot kívántunk teremteni a romániai magyar müszaki kutatók, oktatók munkájának megismertetésére, legújabb eredményeinek bemutatására, megvitatására, az egymás közti kapcsolat kialakítására, hiszen akkoriban Romániában nem volt magyar müszaki felsőoktatás, s így a magyar nyelvü ülésszak jelentősége - az EME Müszaki Tudományok Szakosztályának kitüzött céljaival összhangban - föleg a magyar müszaki nyelv ápolására, fejlesztésére, a magyar-román s román-magyar műszaki szótár szerkesztésének elősegítésére irányult.

A jubileumi ülésszakot 2000. november 25-én tartotta meg a szakosztály az EME Mollházában, mely akkoriban a szakosztály székhelyéül szolgált (a Természettudományi és Matematikai Szakosztállyal közösen). A meghívó/programfüzet borítóján is a Moll-ház fotója szerepel (1. kép). A programfüzet online elérhető az Erdélyi Digitális Adattárban (a továbbiakban: EDA): http://eda.eme.ro/handle/10598/28556.

A fórumot Gyenge Csaba professzor, szakosztályi elnök nyitotta meg, ezt követően bemutatta a szakosztályi titkár által összeállított Az EME Müszaki Tudományok Szakosztály 10 éves története címü írást/összeállítást [6]. (Online elérhető az EDA-ban: http://eda.eme.ro/handle/10598/28574).
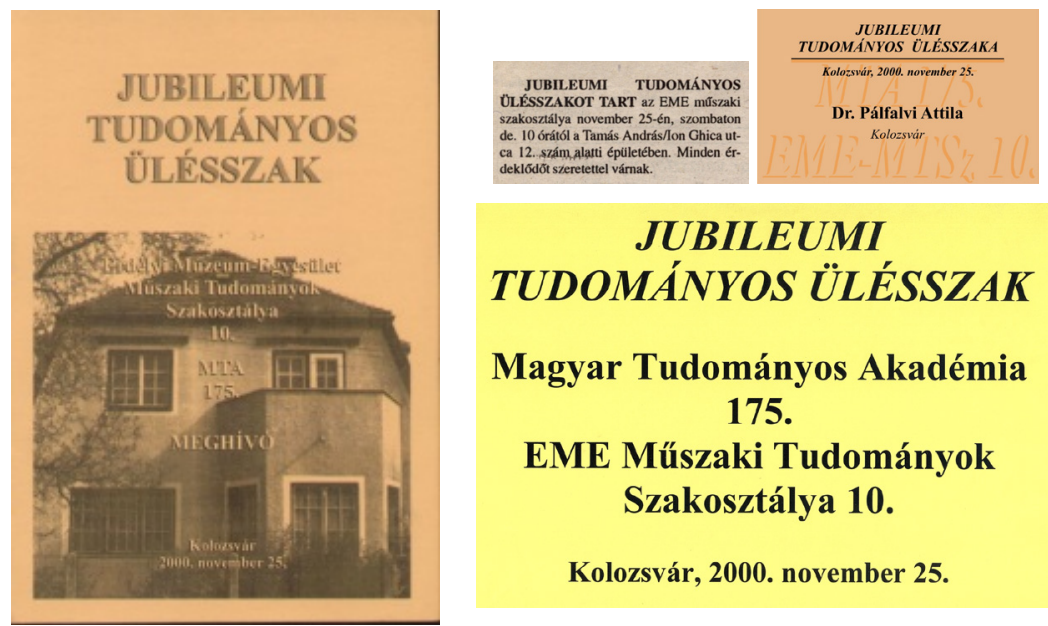

\section{Magyar Tudományos Akadémia} 175.

EME Müszaki Tudományok Szakosztálya 10.

Kolozsvár, 2000. november 25.

1. kép. A jubileumi tudományos ülésszak meghivójának/programfüzetének boritója, a Szabadság Kolozsvári Közéleti Napilapban való meghirdetése (XII. évfolyam, 275. szám, 2000. november 23., 2. oldal), a kitüzője, illetve a plakátja, 2000. november 25.

Az ülésszak plenáris előadását az évfordulók jegyében Benkő Samu, az EME elnöke, az MTA külső tagja tartotta meg A Magyar Tudományos Akadémia és az Erdélyi MúzeumEgyesület címmel (2. kép). 
Ezt követték a müszaki előadások. Az előadók a kolozsvári Műszaki Egyetem három karának oktatóiból, doktoranduszaiból, illetve a marosvásárhelyi Müszaki Egyetem oktatóiból tevődtek össze.

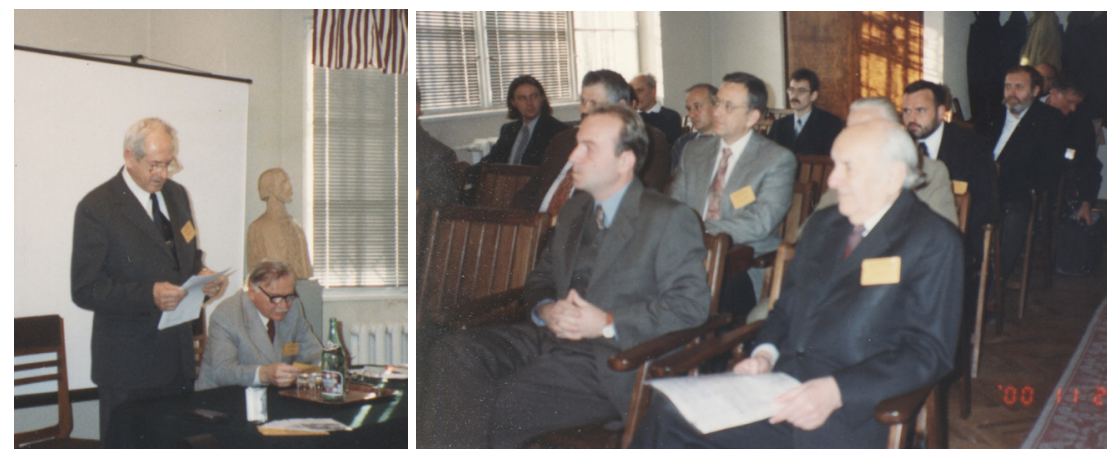

2. kép. A jubileumi tudományos ülésszak a Moll-házban 2000. november 25-én. A bal oldali képen a megnyitó két szónoka: Gyenge Csaba és Benkö Samu, a jobb oldali képen a résztvevök. (Fotó: BE)

A nyitóelőadást Maros Dezső, a kolozsvári Müszaki Egyetem nyugalmazott egyetemi tanára, az MTA külső tagja tartotta Barangolás a müszaki múltamban címmel. Mint rangidős professzor, kutató $\mathrm{s}$ doktoranduszvezető tekintette át müszaki pályafutását, mely a tudományos eredményekre és megvalósításuk körülményeire is kiterjedt.

A kolozsvári Müszaki Egyetem jeles magyar professzorai legújabb kutatási eredményeiket mutatták be. Gyenge Csaba: Integrált versenyképes és környezetvédö termékfejlesztés, Csibi Vencel: Mikromechanika - mechatronika, Szabó Bálint: Tudományos mércével mért intuíció-megfogalmazás alatt a történeti épületek modern tartószerkezet-elmélete, Imecs Mária: A térfázor elméletétől a villamos hajtások vektoriális szabályozásáig, Kerekes László: Minőségbiztositási rendszerek bevezetésének tapasztalatai Romániában, Sándor László: Automata sebességváltók címmel értekeztek.

A doktori iskolát fenntartó professzorok - mint Maros Dezső, Pálfalvi Attila, Gyenge Csaba és Hollanda Dénes - törekvései abban az időben az utánpótlás kinevelésére irányultak, így természetes volt, hogy az ülésszakon néhány doktorandusz kutatási témájába is beleláthattunk. A kolozsvári Müszaki Egyetem magyar doktoranduszai közül az ülésszakon Bitay Enikő: A lézeres felületkezelés számitógépes szimulációja, Kismihály János: Hipoid hajtópárok és a CAD/CAM/CARP, Prezenszky István: Vasporokból hengerelt fémhálóval erősitett szalagok gyártástechnológiája címü előadásai hangzottak el.

A marosvásárhelyi Müszaki Egyetemről Hollanda Dénes egyetemi tanár a Szerszámgépeken generált felületek elmélete címü előadással jelentkezett, de nem lehetett jelen a rendezvényen, helyette Dávid László dékánhelyettes tartott előadást, illetve Máté Márton docens a Forgácsoló szerszámok geometriai optimálásának szempontjai címmel kutatási eredményeit mutatta be. 
A szakosztály fennállásának 10. évfordulóját méltóképpen sikerült megünnepelni a tudományosság, a tudományterjesztés jegyében. Sajtóvisszhangja a kolozsvári közéleti napilapban keletkezett Többszörös évforduló címmel, Csurulya Szidónia tollából [7].

Ezzel az előzménnyel természetesnek számított, hogy a következő év novemberében ismét megrendezik a müszaki tudományosság fórumát A Magyar Tudomány Napjának jegyében.

\section{Műsszaki tudományos ülésszak (MTÜ), 2001}

„Immár hagyományossá vált, hogy minden évben megünnepeljük A Magyar Tudomány Napját. Ennek érdekében ismét Müszaki tudományos ülésszakot tervezünk, amelyre szeretettel meghivjuk. Ugyanakkor felkérjük, hogy egy 10 perces tudományos elöadásban ismertesse legújabb kutatásai irányait és eredményeit", szólt a szakosztályi felhívás (kelt: 2001. szeptember 18-án), felkérő levél (lásd EDA: http://eda.eme.ro/handle/10598/28575).

A második Müszaki tudományos ülésszakot 2001. november 3-án hirdették meg. „A Magyar Tudomány Napját minden évben tudományos ülésszakkal ünnepli meg az Erdélyi Múzeum-Egyesület Müszaki Tudományok Szakosztálya, a szakosztály választmánya nevében ezennel tisztelettel meghívjuk a következö programra..." - szólt a meghívó, melynek szövege a programfüzetben is olvasható (borítója a 4. képen látható). A programfüzet online elérhető az EDA-ban: http://eda.eme.ro/handle/10598/28557.

Jóllehet a rendezvény elsősorban a hazai müszaki alkotók fóruma kívánt lenni, a második rendezvényre első ízben anyaországi előadót is meghívtunk, mert fontosnak tartottuk a határon átnyúló kapcsolatkiépítést, -megtartást. E szempontot a további fórumokon is szem előtt tartottuk. Dudás Illés, a Miskolci Müszaki Egyetem Gépészmérnöki Kara Gépgyártástechnológiai Tanszékének tanszékvezető egyetemi tanára nem először érkezett hozzánk szakosztályunk meghívására, hiszen az 1996-ban elindított Fiatal müszakiak tudományos ülésszakának is ő volt az egyik fö támogatója. Fontosnak tartotta a szakosztály kezdeményezését, a határon átnyúló müszaki tudományosságot, a kapcsolatok ápolását, a szakmai értékek ily módon való terjesztését. Az ő nevét találhatjuk a 2002. évi programfüzet támogató listáján is, mindig készen állt a tudományos kezdeményezések megsegítésére.

A megnyitón Gyenge Csaba szakosztályi elnök beszédében azt hangsúlyozta ki, hogy mennyire fontos az akadémiai intézményeket fenntartani, hiszen az MTA is így jött létre, valamennyi tudós és mecénás lelkes hozzáállásából, adományából.

Tonk Sándor történész, az EME alelnöke, beszédében (3. kép) azt a tényt emelte ki, hogy az „Erdélyi Múzeum-Egyesület megalakulása óta az erdélyi magyarság önismeretét, az önazonosság tudatát ápolja. Joggal tesszük fel a kérdést, hogy a müszaki, a természettudományi ismereteknek hol a helye ebben.".

A felvetett kérdést meg is válaszolta: „Az elmúlt egy évszázadban az Erdélyi MúzeumEgyesület bebizonyitotta azt, hogy igenis ezekre az ismeretekre szüksége van a közösségünknek. Természetes az, hogy nem tudunk felvállalni alapkutatásokat. De azt, hogy a magyar 
nyelvvel müveljük a tudományt, és a magyar nyelven népszerüsitsük a tudománynak az eredményeit, ez a Múzeum-Egyesületnek feltétlenül a feladata".

Majd az EME válságos, útkereső időszakára utalt. Jelentősnek tartotta azonban azt, hogy az EME-nek csupán folytatnia kell az erdélyi magyar tudománymüvelést, vissza kell találnia az útra. Zárszavában a rendezvény jelentőségére utalt: „Úgy gondolom, hogy egy ilyen öszszejövetel, találkozás, valójában lehetöséget jelent arra, hogy felhívjuk, biztassuk az embereinket, hogy érdemes ezt a munkát folytatni, érdemes ezért áldozatot hozni”.
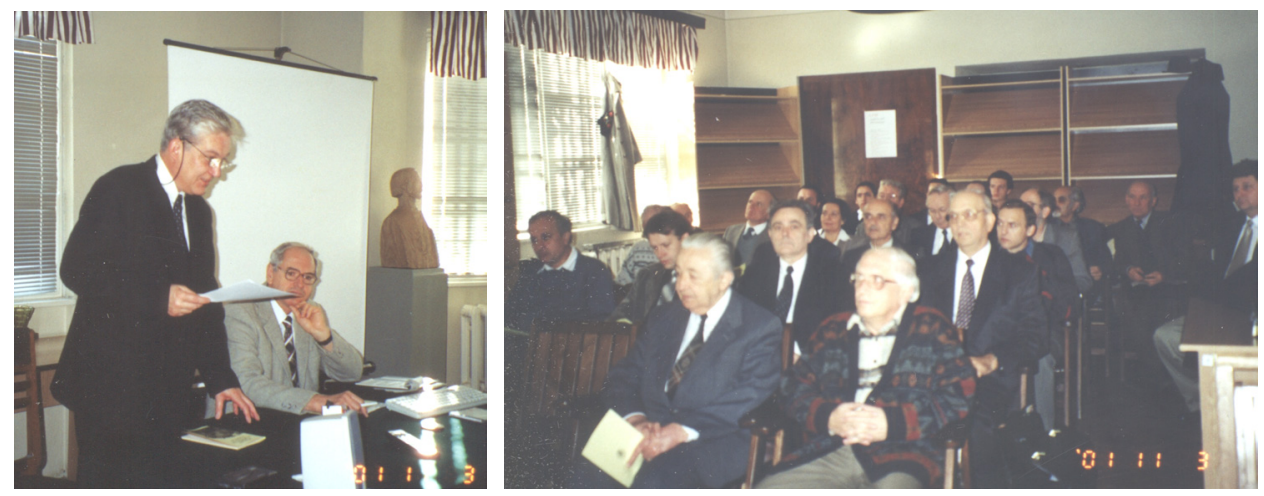

3. kép. A jubileumi tudományos ülésszak a Moll-házban, 2001. november 3-án. A bal oldali képen a megnyitó beszédek szónokai: Tonk Sándor és Gyenge Csaba; a jobb oldali képen a résztvevők. (Fotó: BE)

Plenáris előadást Dudás Illés, a Miskolci Egyetem professzora tartott a Környezetvédelem, környezetbarát technológiák magyarországi helyzetéről. Gyenge Csaba, a kolozsvári Müszaki Egyetem professzora, az EME Müszaki Tudományok Szakosztálya keretében 1996-ban elindult Fiatal müszakiak tudományos ülésszaka öt évének eseményeiről számolt be. Ezt követően a müszaki tudományok különböző területeiről, a legfrissebb kutatási eredményeikről tartottak előadást: Prezensky Tibor Béla: Nagyteljesitményü lefejtő-csigamaró bemutatása; Bitay Enikő: Lézeres felületkezelés; Kismihály János: Új idők, új módszerek; Szőcs Katalin: A kalapácsmalmok hatásfokának növelése; Mezei Sándor: A megmunkálási sorrend optimálása; Prezensky István: Többrétegü porózus fémszalagokat gyártó berendezés; Selinger Sándor: Erdélyi magyar müemlékek térinformatikai katasztere címmel.

A tudományos ülésszak pohárköszöntővel, kötetlen beszélgetéssel és szakkiadványok cseréjével zárult (4. kép).

A rendezvényről a kolozsvári Szabadság napilapban A Magyar Tudomány Napján Müszaki tudományos ülésszak az EME-nél címmel jelent meg Ördög I. Béla írása, melyből a megnyitóról és a két plenáris előadásról kapott képet az olvasó [8].

A Müszaki tudományos ülésszak ezzel beépült a köztudatba, s évi rendszerességgel kiemelt fóruma lett a szakosztálynak, akárcsak a fiatal müszakisoknak szánt márciusi rendezvénye, az FMTÜ (A Fiatal müszakiak tudományos ülésszaka hagyományosan minden év márciusának harmadik hetében zajlik le). 


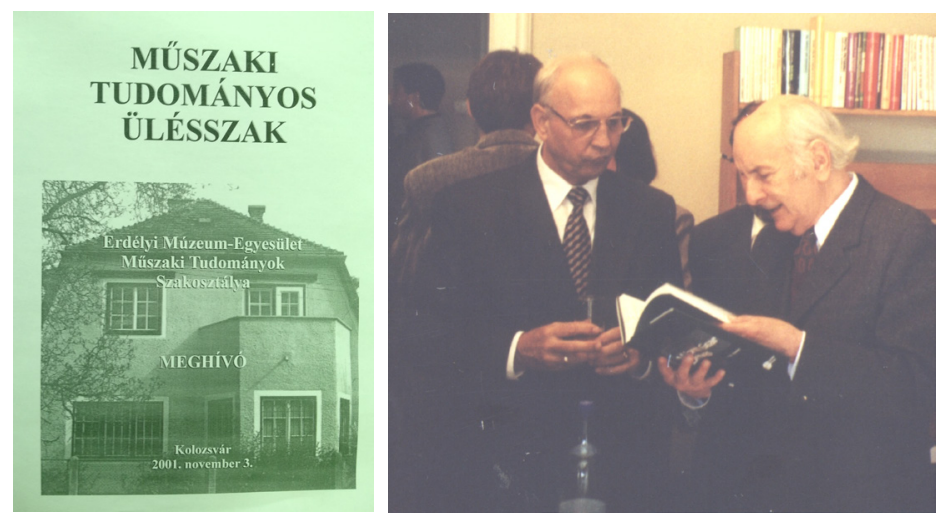

4. kép. A második Müszaki tudományos ülésszak meghívójának/programfüzetének boritója, illetve fotó Dudás Illés és Maros Dezső professzorokról a II. MTÜ-n, Kolozsvár, Moll-ház, 2001. november 3. (Fotó: BE)

\section{Múszaki tudományos ülésszak, 2002}

Az első két ülésszak sikere is hozzájárult ahhoz a döntéshez, hogy az EME elnöksége 2002-ben elindítsa A Magyar Tudomány Napja Erdélyben (MTNE) elnevezésü fórumát, felölelve a szakosztályok által is képviselt valamennyi tudományterületet.

Az előkészítő munkálatokban és a szervezésben meghatározó szerepet vállalt az EME Müszaki Tudományok Szakosztálya, a korábbi évek tapasztalataira támaszkodva. A szakosztály fontosnak tartotta, hogy a többi tudományterület is bekapcsolódjék, hiszen a fórum a tudománynépszerüsítés mellett kiváló alkalom a szakmai kapcsolatteremtésre, a különböző generációk szakmai együttmüködésére, illetve a tudós társadalom közösségének építésére.

Egyed Ákosnak, az EME akkori elnökének javaslatára A Magyar Tudomány Napja Erdélyben fórum időpontját az Erdélyi Múzeum-Egyesület megalakulásának évfordulójára, alapításának napjára (1859. november 23-26.) 2002. november 23-ára tüztük ki. A tervek szerint a fórum első napján általános, időszerü téma került napirendre, melyen valamennyi szakterület meghívottjai tartottak előadást, a második nap a tudományos szakosztályoké, a tematikát maguk határozván meg.

Természetes volt, hogy a tudományos rendezvényt a Magyar Tudományos Akadémia Magyar Tudomány Napi fórumának részeként kívánjuk kibővíteni régiónkban is. Az MTA-t a rendezvényen Vizi E. Szilveszter, az MTA elnöke képviselte, aki üdvözlőbeszédében emlékeztetett az 1859-es alapító közgyülésen gróf Mikó Imre szájából elhangzott célkitüzésekre. „Mai viszonylatban a magyarság kötödéspontja a szellem müködése, és az anyaország kötelessége ebben segiteni az országhatárokon túl élö és alkotó magyarokat. A 21. században a tudás + információ = hatalom képlet uralja az emberiséget, ehhez kell nekünk hozzáadnunk az erkölcsöt, hiszen a tudomány célja az igazságkeresés. Mindnyájan a magyar 
nemzet részei vagyunk egy olyan kontinensen, amely nem az államok, hanem a nemzetek Európája".

Egyed Ákos elnöki beszámolójában az EME tevékenységét, helyzetét vázolta, kifejtve, hogy mindezen tudományos tevékenységhez számít az MTA támogatására [9].

Ezt követően sor került az MTA és az EME közötti együttműködési nyilatkozat aláírására. Célja „, a tudományos utánpótlás biztositása, az intézményfejlesztés, a strukturális támogatás, a külsö kapcsolatok megerösitése a magyar tudományosság egységéért, a regionális kutatás fokozása, a könyvtárak és általában az infrastruktúra korszerüsítése, a könyv- és folyóirat-kiadások, valamint az erdélyi tudományosságon belüli együttmüködés ösztönzése, egy akadémiai kutatóhálózat kiépítése” (5. kép).
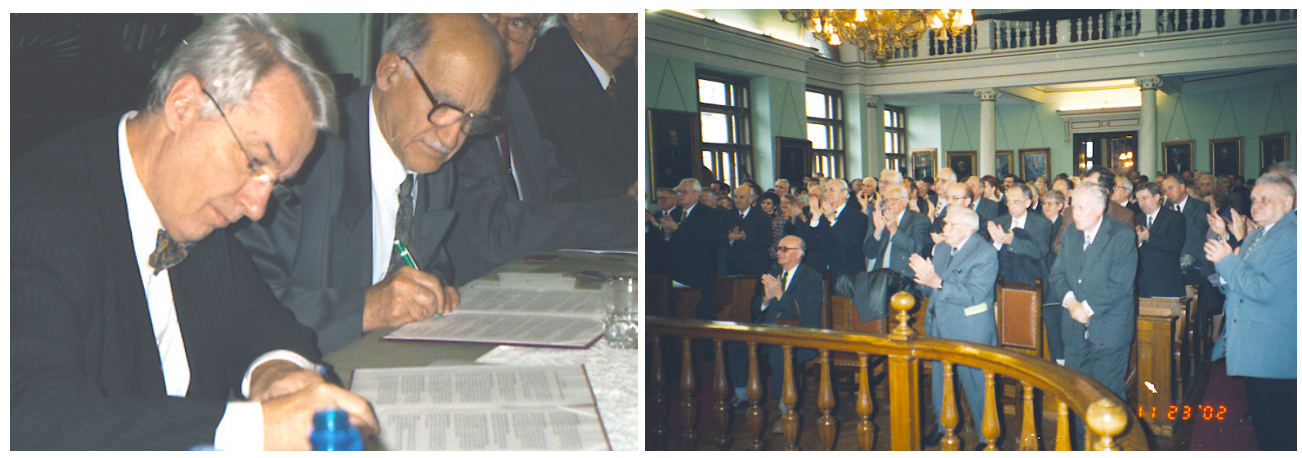

5. kép. Az EME-MTA együttmüködési megállapodás aláirása (Vizi E. Szilveszter MTA-elnök és Egyed Ákos EME-elnök) A Magyar Tudomány Napja Erdélyben címü fórum megnyitóján, 2002. november 21., Kolozsvár, a Protestáns Teológiai Intézet díszterme. (Fotó: BE)

A tudományos elöadások következtek. A fórum témája: Céljaink, lehetőségeink a tudománymüvelésben volt, a felkért elöadók ennek jegyében beszéltek. Jakó Zsigmond, az EME tiszteletbeli tagja, a humán- és társadalomtudományok erdélyi helyzetét ismertette. Markó Bálint (az EME Természettudományi és Matematikai Szakosztályának elnöke) a természettudományi kutatások lehetőségeiről értekezett. Brassai Zoltán marosvásárhelyi professzor az orvostudományi kutatások időszerü erdélyi kérdéseit tárta fel, Gyenge Csaba, az EME alelnöke pedig a müszaki tudományok jelenéről és jövőjéről fejtette ki véleményét.

Délután a Házsongárdi temetőben leleplezték azt az emléktáblát, amely a Magyar Tudományos Akadémia ott nyugvó tagjainak névsorát tünteti fel Bölöni Farkas Sándortól Csürös Istvánig [10]. A névsor azóta sajnos bővült: Imreh István (2003), Kékedy László (2004), Faragó József (2004), Kiss István (2004), Jakó Zsigmond (2008), Csetri Elek (2010), Maros Dezső (2011), ahogyan a fotón látható (6. kép).

Vizi E. Szilveszter az emléktábla előtt elmondott beszédében újra utalt arra, hogy: „ez a nap a magyar tudományosság újraegyesitésének fontos pillanata”. 
Ezt követően az EME öt szakosztálya párhuzamos szekciókban kezdhette el a munkát a Protestáns Teológia Intézet előadótermeiben. Ekkor hangzottak el a III. Müszaki tudományok ülésszak elöadásai is.

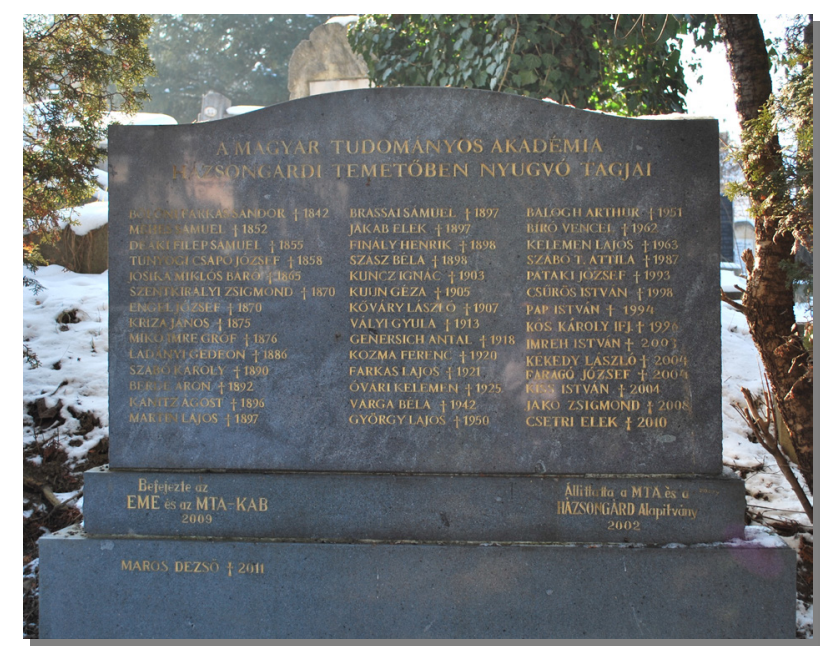

6. kép. Az MTA Házsongárdi temetőben nyugvó tagjainak emléktáblája (Fotó: BG).

A szakosztályi fórum megnyitóját követően Kerekes Sándor, a Kolozs megyei Tanács alelnöke az ipari parkok fejlesztését és gazdasági hasznosságát mutatta be, majd a kolozsvári, miskolci, temesvári, marosvásárhelyi, brassói és nagybányai müszaki egyetemek profeszszorai, kutatói értekeztek legfrissebb kutatásai eredményeikről. Sorrendben Kerekes Sándor: Az ipari parkok mint a gazdaságfejlesztés eszközei, Gyenge Csaba: CNC fogköszörülés, Dudás Illés: Csavarfelületek korszerü gyártásgeometriája, Delesega Gyula: Szakaszolók melegedésének számitógépes eredményei, Selinger Sándor: A térinformatika és a fenntartható fejlődés, Dávid László: Mesterséges intelligencia alkalmazása a müszaki tudományokban, Bíró Károly: Új típusú villanymotorok, Csibi Vencel: Különleges fogaskerékhajtások a mechatronikában, Varga Béla: Aluminium a gépkocsiiparban, Bitay Enikő: Kopásállóság növelése lézeres felületkezeléssel, Kerekes László: Irányítási és biztonsági rendszerek bevezetésének jelentősége Románia EU-csatlakozásának előkészitésében, Szabó Bálint: Történeti tartószerkezetek és a kulturális örökség, Köllö Gábor: A XXI. század vasúti közlekedése, Pay Jenő: Hordócsigás hajtómüvek, Sándor László: Az autóipar történetéről címủ előadások hangzottak el. Elolvasható a rendezvény részletes programjában, mely ezúttal A Magyar Tudomány Napja Erdélyben, az EME teljes rendezvényének programpontjait tartalmazza, a központi fórumét, illetve az öt szakosztályét. Ebben található a Müszaki tudományos ülésszak programja is (13-15. oldalakon), online elérhetö: http://eda.eme.ro/handle/10598/28558. A szakosztályi rendezvény értékelö jegyzőkönyvét a 7. kép szemlélteti. „A szekció igen nagy érdeklödés közepette zajlott le. Intenzív diskurzus... a technikai kivitele az elöadásoknak mintaszerü, a technika üzemeltetése kitünö... Köszönjük 
a kitünö szervezést az EME Müszaki szakosztályának" - olvasható az ülésszak értékelö jegyzőkönyvében Dudás Illés társelnöknek, a Miskolci Egyetem professzorának bejegyzéseként.
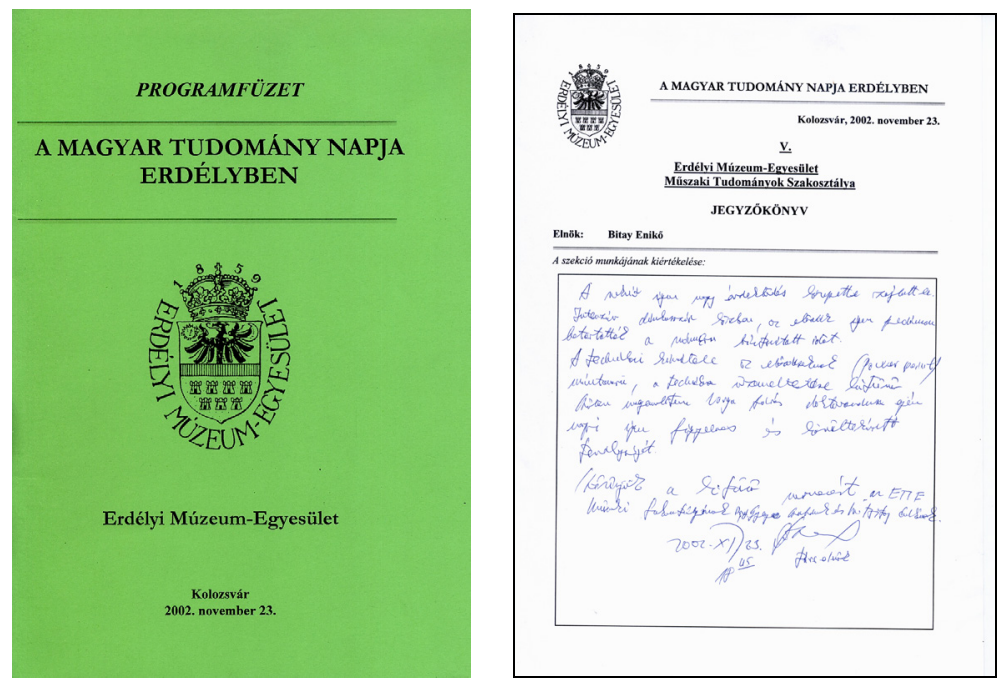

7. kép. A Magyar Tudomány Napja Erdélyben programfüzetének boritója, illetve a harmadik Müszaki tudományos ülésszak jegyzőkönyve az ülésszak munkálatairól, 2003. november 22.

\section{Műsszaki tudományos ülésszak, 2003}

A Magyar Tudomány Napja Erdélyben fórumot 2003-ban is életre hívtuk, november 2122. között. A rendezvény kétnaposra bővült, helyet adva így az első napi tematikus elöadásoknak. „... több időt szeretnénk forditani a kutatás eredményeinek bemutatása és megvitatása mellett a tudományos munka általános kérdéseire is" - olvashatjuk Egyed Ákos EMEelnök köszöntőjében, a programfüzet borítóját a 8. kép szemlélteti (az EDA-ban online elérhetö: http://hdl.handle.net/10598/28559). A rendezvény fóvédnökségét Vizi E. Szilveszter, az MTA elnöke vállalta, s ettől az évtől kezdve mindig az MTA mindenkori elnöke vette védnöksége alá a fórumot.

A régiókutatás időszerűsége jegyében Meskó Attila, az MTA főtitkárhelyettese beszámolt a nemrég Budapesten tartott World Science Forum tudományos ülésszak következtetéseiről, míg Berényi Dénes, az MTA Magyar Tudományosság Külföldön Elnöki Bizottságának elnöke a tudomány európai vonatkozású távlatait vázolta. Pomogáts Béla irodalomtörténész nem lehetett jelen a rendezvényen, Sipos Gábor, az EME fótitkára olvasta fel a tudós regionális, nemzeti és európai irodalomról szóló dolgozatát.

A délután folyamán Benedek József a regionális kutatási paradigmákról és a régiósításról, Kolumbán Gábor a régiókutatás módszeréről, Selinger Sándor a térinformatikáról mint a régiófejlesztés nélkülözhetetlen eszközéről, Pozsony Ferenc a népi kultúra táji ta- 
goltságának kutatásáról Erdélyben és Moldovában, Balla Árpád Hargita megye 1970-2002 közötti népmozgalmi adatairól, Csávossy György pedig az erdélyi borok tájiságáról értekezett. A központi fórumról, az első napról a Krónika és a Szabadság napilapok számoltak be $[11,12]$.

2003. november 22-én, a második napon a szakosztályok párhuzamos szakmai mühelytalálkozóira került sor.

A Müszaki tudományos ülésszak programja ebben az évben is a központi MTNE fórum programfüzetében szerepelt, nem készült külön füzet (a MTNE programfüzet online elérhető az EDA adattárában: http://eda.eme.ro/handle/10598/28559, melynek 17-18. oldalán a Müszaki Tudományok Szakosztály rendezvényének programja olvasható).

A felhíváskor a szervezők első alkalommal kísérelték meg, hogy az előadások írott anyagát előre begyüjtsék (ehhez formai követelményt tartalmazó leírást is mellékeltek), publikálási szándékkal. Sajnos ez a kísérlet nem vált be, ezért külön programfüzetet sem volt érdemes készíteni.

Fordulópontot jelentett a helyszín megválasztása, először vettük igénybe a Sapientia Erdélyi Magyar Tudományegyetem vendégszeretetét, a rendezvényhez való hozzájárulásukat. Azóta a helyszín hagyományossá vált, sőt, nem csupán a Müszaki tudományok ülésszakának rendezvényeit, hanem a következő évtől a Fiatal müszakiak tudományos ülésszakának 1. és 2. szekcióját is ott tartjuk.

A müszaki tudományos fórumot Szirtes Tamás nyugalmazott kanadai professzor nyitotta meg Dimenzió-analízis a müszaki és tudományos gyakorlatban címü előadásával; Kerekes Sándor, a Kolozs megyei Tanács alelnöke Régiópolitika és vidékfejlesztés címmel mutatta be az újabb fejlesztési terveket.
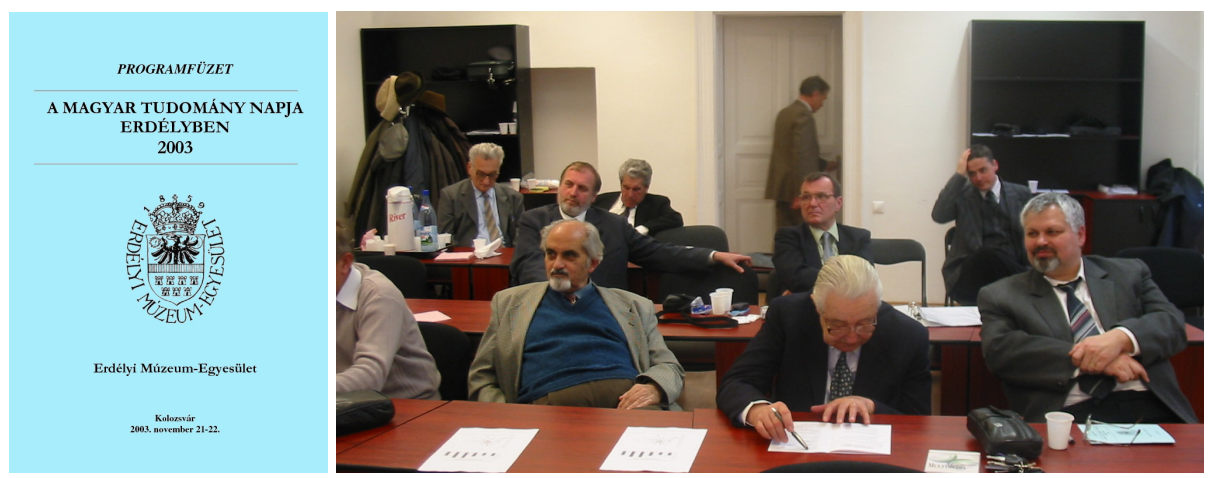

8. kép. A Magyar Tudomány Napja Erdélyben 2003 programfüzetének boritója, illetve a harmadik Müszaki tudományos ülésszak fotója, 2003. november 22. (Fotó: BE)

Ebben az évben volt először többszerzős előadás, mely jellemző a müszaki alkotásokra, hiszen komoly eredmények eléréséhez csapatmunkára van szükség. A legújabb közös kuta- 
tásaikat mutatta be Gyenge Csaba professzor doktoranduszával, Varga Andrással: Versenyképes termékfejlesztés az erdélyi kis- és középvállalatokban címmel.

Ezt követően kolozsvári, marosvásárhelyi, gyergyószentmiklósi és brassói kutatók, egyetemi oktatók, doktoranduszok következő előadásai hangzottak el: Géczi Róbert: Észrevételek a székelyföldi régió versenyképességének megitéléséhez; Szakács József: A modern technológiai tudomány szerepe a régiófejlesztésben; Kerekes László: Integrált menedzsmentrendszerek - a romániai piac új kihívása; Csibi Vencel: Fogaskerékhajtások kutatása Erdélyben; Dávid László: Mesterséges idegsejthálók alkalmazásai a folyamatirányításban; Márton László: Erdélyi bronzharangok károsodási formáinak összefoglaló elemzése; Varga Béla: Szinesfémöntödék szerepe régiónk fejlödésében; Szabó Bálint: Az épitett kultúra regionális kérdései Erdélyben; Furu Árpád: Torockó - egy erdélyi történeti régió újjászületett történeti köntösben. A programfüzet, az elöadók adataival online elérhető az EDAban: http://hdl.handle.net/10598/28559.

\section{Müszaki tudományos ülésszak, 2004}

A Magyar Tudomány Napja minden év novemberében életre kelt, a központi fórumnak meghatározott témája volt. A szakosztályok külön, önállóan szervezkedtek. A következőkben rájuk már nem térünk ki részletesen, a müszaki rendezvényre összpontosítunk, s ezeknél is csupán a sajátos, arra az évre jellemző eseményre, információra. Felsoroljuk az előadókat $\mathrm{s}$ előadásuk címét.

Mivel 2003-ban nem sikerült az előadások írott anyagait begyüjteni, így ebben az évben a magyar nyelvü rövid kivonataikat kértük el. A rendezvény meghirdetésére elkészült a szakosztály programfüzete, mely előszót, az előadók adatait, az előadások időpontját, címét, illetve az említett kivonatokat tartalmazta. A füzet utolsó oldalán pedig a soron következő rendezvénynek a meghívója volt (az FMTÜ 2005. márciusi fórumára). Tehát a füzet amolyan szakosztályi tudósító, hírlevél szerepet töltött be.

A programfüzet borítóját a 9. kép szemlélteti, online elérhető az EDA-ban: http://eda.eme.ro/handle/10598/28566.

A résztvevők, előadók többnyire visszajáró személyek, kutatók, oktatók, érdekes volt követni a folyamatokat: hallani az adott évi kutatásaik, munkájuk újabb eredményeit, fejleményeit.

Minden évben igyekeztünk egy-egy jeles határon túli müszaki személyiséget megszólítani. 2004-ben a Szabadkai Müszaki Szakfőiskola főigazgatója, Nyers József egyetemi tanár tisztelt meg bennünket jelenlétével, s tartott Megújuló energiaforrások és berendezések címmel előadást.

Ebben az évben is voltak többszerzős előadások, utalva a kialakuló kutatócsapatok mühelymunkájára. A következő előadások hangzottak el időrendi sorrendben: Kerekes Sándor: Terület- és vidékfejlesztési tervek térinformatika segitségével; Kerekes László: Integrált irányitási rendszerek - a biztonságos és hatékony vállalatvezetés eszköze; Brassai Sán- 
dor Tihamér, Dávid László, Bakó László: CMAC típusú mesterséges neurális hálózat hardware megvalósitása és folyamatirányításban való alkalmazása; Kismihály János: HSC-HPC, Nagy sebességü ás nagy teljesitményü marási eljárások és szerszámok; Gyenge Csaba, Varga Zsolt, Gyenge Zoltán: Környezetbarát technológiák a gépgyártásban; Márton László: Napórakutatások Hargita megyében; Varga Béla: Öntészeti alumíniumötvözetek gáztalanítása.
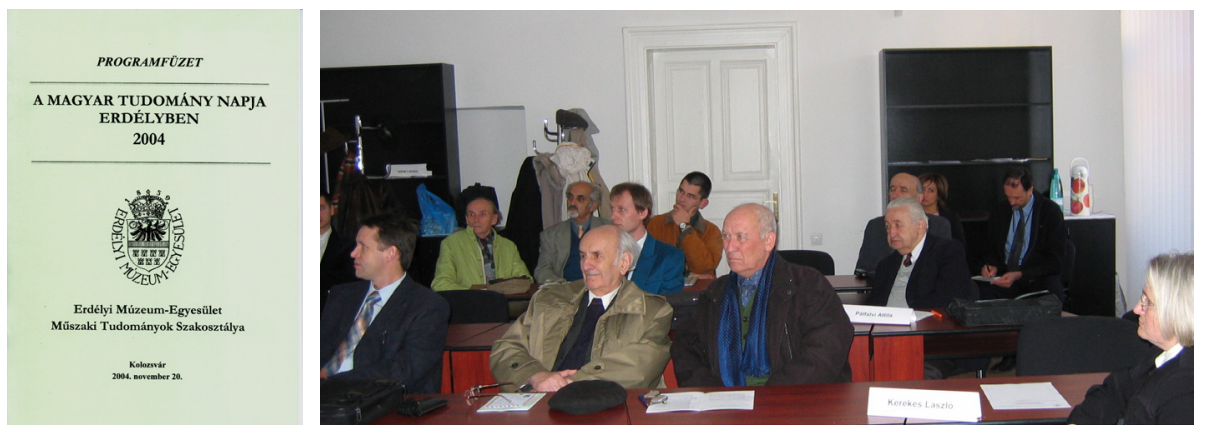

9. kép. A Magyar Tudomány Napja Erdélyben rendezvénysorozat keretében megszervezett Müszaki tudományos ülésszak programfüzetének boritója, a rendezvény fotója, 2004. november 20. (Fotó: BHZ)

\section{Mû́szaki tudományos ülésszak, 2005}

2005-ben a szakosztály a kutatási eredményei alapján az MTNE központi fórumának témájába illeszkedő előadással képviseltette magát. Szakács József, Bitay Enikő Müszaki kutatások és fejlesztések Erdélyben a XX. századig címü tanulmányát Szakács József nyugalmazott fökutató mutatta be 2005. november 18-án. A központi fórum elöadásait a következő évben az EME egy közös kötetben jelentette meg: Ilyés Szilárd, Tamásné Szabó T. Csilla (szerk.): Az erdélyi magyar tudománytörténet. A Magyar Tudomány Napja Erdélyben 2005. évi fórumán elhangzott elöadások. Az EME kiadása, Kolozsvár, 2006. (online itt érhetö el: http://hdl.handle.net/10598/15469).

2005. november 19-én, akárcsak az előző évben, az EME Müszaki Tudományok Szakosztálya a Sapientia EMTE központi épületében szervezte meg immár a 6. Müszaki tudományos ülésszakot. A korábbi évhez hasonlóan készült el a programfüzet az előadások magyar nyelvü kivonataival. A Magyar Tudomány Napja Erdélyben rendezvénysorozat keretében megszervezett müszaki ülésszak (2005. november 19.) programfüzetének borítója a 10. képen látható, teljes terjedelemben az EDA-ban online elérhető: http://hdl.handle.net/10598/28561.

A müszaki fórumon a következő előadások hangzottak el: Kerekes Sándor: Kolozs megye hosszú távú fejlesztési terve; Gyenge Csaba: Integrált termékfejlesztés és gyorsprototipizálás; Dávid László, Gyenge Csaba, Bakos Levente: Hagyományos és holonikus termelésütemezés összehasonlitása kritikus út módszerére alapuló algoritmus 
által; Hollanda Dénes, Tolvaly-Roşca Ferenc: Fogaskerékhajtáspontosság-vizsgálatok számítógépes testmodelleken; Csibi Vencel, Noveanu Simona: Elasztikus kötések a mechatronikában; Orbán György: Számítógép alkalmazása az ivelt fogú kúpkerékhajtások kapcsolódásának tanulmányozásában; Gobesz Ferdinánd-Zsongor: Számítógéppel segédelt tanulás az épitészetben; Márton László: A segesvári óratorony harangjairól; Szőcs Katalin: A természeti és müszaki ismeretek jelképes ábrázolása; Baki-Hari ZoltánGábor: Termékfejlesztés tegnap s ma.
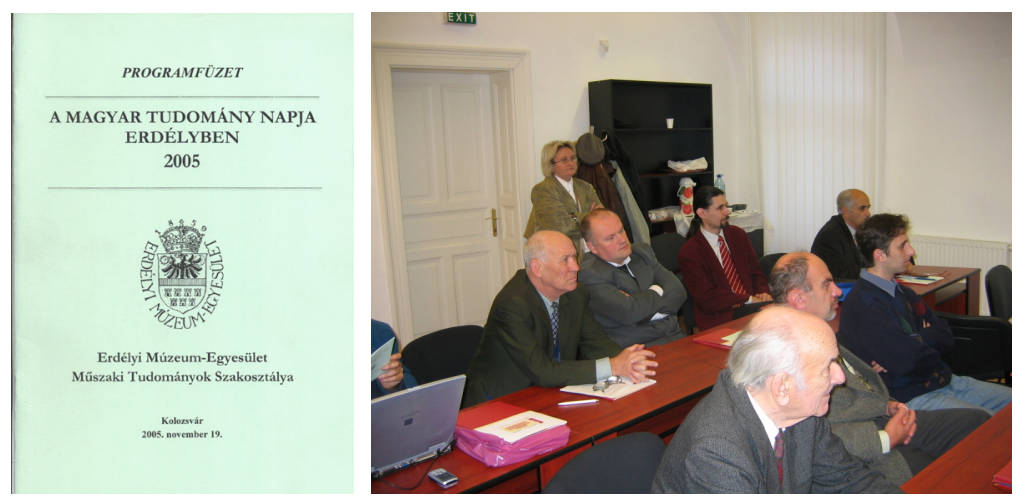

10. kép. A Magyar Tudomány Napja Erdélyben rendezvénysorozat keretében megszervezett Müszaki tudományos ülésszak programfüzetének boritója, illetve fotója, 2005. november 19. (Fotó: BHZ)

\section{Műszaki tudományos ülésszak, 2006}

A hetedik ülésszak 2006. november 25-én zajlott le, a megszokott módon. A rendezvény programfüzetét ezúttal háromnyelvű kivonattal (magyar, román és angol nyelvü) bővítettük, arra való tekintettel, hogy néhány kutatócsoportban román anyanyelvü kutató is részt vett, ezzel megkönnyítettük a szakmai kommunikációt. Nem titkolt célunk volt az is, hogy példát mutassunk a multikulturális szemléletröl, ne csak követeljük az anyanyelvü szakmai oktatást.

A programfüzet borítóját a 11. kép szemlélteti, teljes tartalma itt olvasható: http://eda.eme.ro/handle/10598/28567.

Meghívott előadóvendégünk ezúttal Sikolya László, a Nyíregyházi Főiskola Műszaki és Mezőgazdasági Karának dékánja volt, aki intézményét s az általuk felkarolt kutatási témákat mutatta be.

Az előadásokat két modulban tartottuk meg. Nevezetesen: Kerekes Sándor: Kolozs megye fejlesztési terve a 2007-2013. időszakra; Gyenge Csaba, Varga András, Gyenge Zoltán, Costea Ancuța: Kockázat alapú karbantartási módszer bevezetése az erdélyi ipari vállalatokban; Kerekes László, Csernátoni Zsuzsanna: Környezeti tényező és hatásfelmérés - a környezet központú irányitási rendszerek kiépitésének hatékony eszköze; Máté Márton, Hollanda Dénes: A hengeres fogaskerekek lefejtésekor keletkezö valós származtató felüle- 
tek; Torkos Zoltán: Ipari cégek és kutatóintézetek nemzetközi együttmüködése az Európai Unió által támogatott kutatás-fejlesztési projektekben; Kismihály János: Nagyteljesítményü keményfém marószerszámok; ifj. Orbán György: Urbanisztikai és épitészeti megfontolások az iszlám tradiciók kortárs értelmezésében; Baki-Hari Zoltán-Gábor: Flexibilis szerszámok gyártása MoldFusion technológiával; Szabó Bálint: Épitett örökségvédelem a Brétfüben; Márton László: Mozzanatok a székelyföldi vasgyártás történetéből; Szőcs Katalin: A madár mint a természeti ismeretek egyik szimbóluma.

Az előadások sokszínűségéről a különböző műszaki szakterületekről érkezett előadók kutatási témái gondoskodtak. Hallhattunk értekezést a korszerü gyártástechnológiákról és szerszámokról, a környezetvédelemről, a kockázat alapú karbantartásról, a területfejlesztésről, az urbanisztikáról, a müemlékvédelemről s a technikatörténetről, ahogy ezt az ülésszak jegyzőkönyve is tanúsítja.
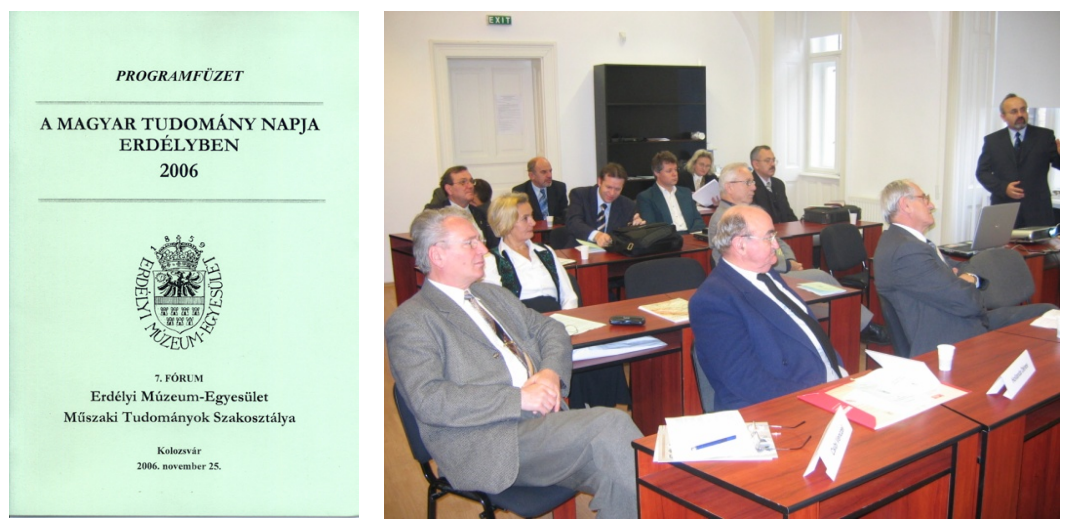

11. kép. A Magyar Tudomány Napja Erdélyben rendezvénysorozat keretében megszervezett hetedik Müszaki tudományos ülésszak programfüzetének boritója, illetve fotója, 2006. november 25. (Fotó: BHZ)

\section{Mû́szaki tudományos ülésszak, 2007}

A nyolcadik fórum a Sapientia EMTE nagy létszámú részvételével emelkedik ki a többi közül. Beleláthattunk a fiatal intézmény két karának tudományos kutatási törekvéseibe, s az elért eredményeket is értékelhettük. Az ülésszakot a csapatmunka jellemezte, az elhangzott tizenhat előadásnak összesen 46 szerzője volt.

A programfüzet ezúttal is háromnyelvü volt, borítóját a 12. kép szemlélteti, teljes tartalma itt olvasható: http://hdl.handle.net/10598/28568.

Az előadásokat két csoportban adták elő. Kiemelt előadást Lányi Szabolcs egyetemi tanár tartott A csíkszeredai biomérnöki szakok (a Müszaki és Természettudományi Tanszék) tudományos tevékenysége címmel.

Ezután mutatták be a kar munkatársai (oktatók, kutatók) csoportos kutatási eredményeiket, az első szerzők által. Mara Gyöngyvér, Kerekes Zsófia, Szakács Gyöngyike, György 
Éva, Ábrahám Beáta, Mészáros Sándor, Lányi Szabolcs: A molekuláris biológiai módszerek használatának lehetőségei a biokorróziót okozó gombafajok azonositásában; Ábrahám Beáta, Miklóssy Ildikó, Albert Csilla, Székely Annamária, Mara Gyöngyvér, Mészáros Sándor, Csutak Éva, Lányi Szabolcs: A xilóz izomeráz enzim heterológ expressziója, tisztitása és aktivitásmérése; Máthé István, Márialigeti Károly, György Éva, Biró Klára, Benedek Tibor, Szász Emőke: Természetes szennyezésbontó aktivitás becslése szénhidrogénekkel szennyezett talajokban; Mészáros Sándor, Máté Szilárd, Mészáros Ildikó, György Éva, Mara Gyöngyvér, Ábrahám Beáta, Lányi Szabolcs: Folyóvizek online monitoringja.

Ebben az évben a bemutatott kutatási témákat nem csupán az intézményközi kapcsolatok jellemezték. Az ipar, a kutatóintézetek is szép számban képviseltették magukat a hagyományosan jelen levő felsőoktatási intézmények mellett.

Az alábbi előadások hangzottak el: Gobesz Ferdinánd-Zsongor: Ökologikus épitkezési informáló rendszer; Kerekes László: Munkahelyi egészség-és életbiztonsági menedzsment rendszerek bevezetése; Tamás Levente, Lazea Gheorghe, Iváncsy Szabolcs: Jelfúziós technikák pozicióméréshez; Hollanda Dénes, Máté Márton: Az egyenes fogú metszőkerék geometriai sajátosságainak javitási lehetőségeiröl; Gyenge Csaba: A profilkorrekciós hengeres fogaskerekek komplex digitális ellenőrzésének adatfeldolgozása és kiértékelése; Kovács József, András József: A romániai külszini fejtésekben található lignit és a jellegzetes meddőkőzetek forgácsolási jellemzőinek meghatározásával kapcsolatos kutatások eredményei; Torkos Zoltán: Új felfogások alkalmazása a tervezésben a Disher Design cégnél; Kismihály János: Keménymarás alkalmazása Gleason marófejek elöállítására; Márton László, Bitay Enikő, Talpas János: Technikatörténeti örökség a kalotaszegi Magyarvalkón; Udvardy László Gergely: Integrált Közút Management Rendszer - egy közúti stratégia konceptusa és modellje; Baki-Hari Zoltán-Gábor: A müszaki tudományok és a társadalom közötti kapcsolat.

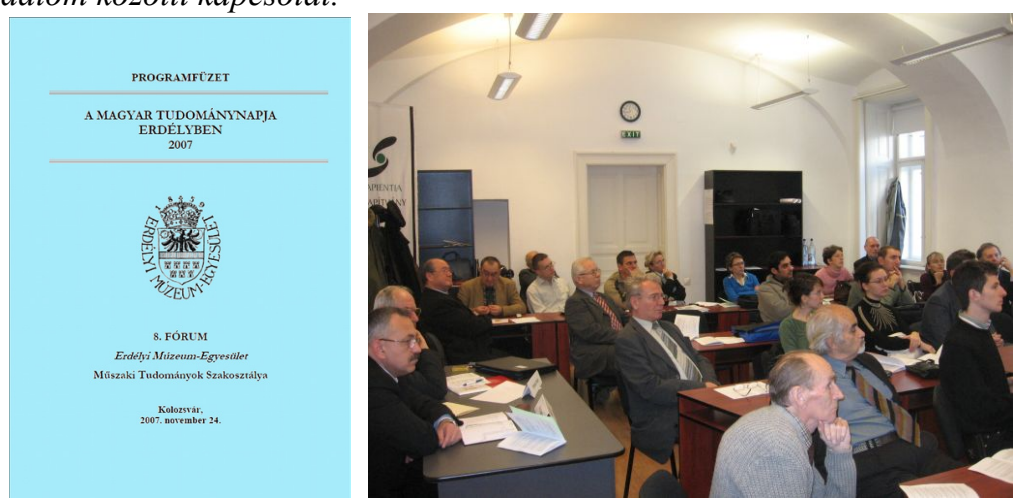

12. kép. A Magyar Tudomány Napja Erdélyben rendezvény keretében megszervezett nyolcadik Müszaki tudományos ülésszak programfüzetének boritója, illetve fotója, 2007. november 24. (Fotó: BHZ) 


\section{Múszaki tudományos ülésszak, 2008}

A kilencedik ülésszak 2008. november 22-én zajlott le. A szép számú, változatos témájú előadást háromnyelvü programfüzet hirdette meg, amely technikai információkkal is bővült (közlekedési eszközök, ajánlott taxik, fontosabb címek, eligazító térkép), online itt olvasható: http://hdl.handle.net/10598/28569 (borítóját a 13. kép szemlélteti).

Nőtt a résztvevők száma, és a magyarországi intézmények oktatói és kutatói is előszeretettel kapcsolódtak be a fórum szakmai munkájába, egyharmad részben képviseltették magukat. Mindkét tendencia tart azóta is.
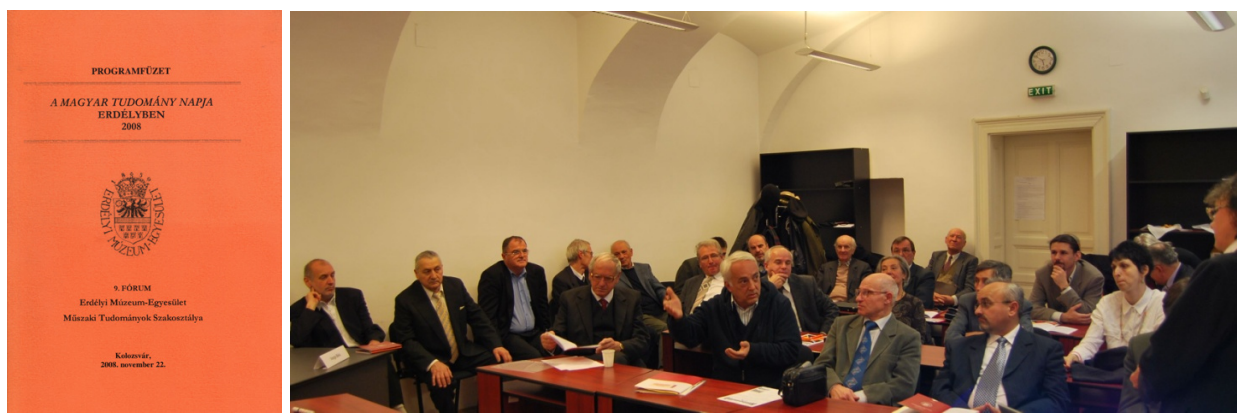

13. kép. A Magyar Tudomány Napja Erdélyben rendezvénysorozat keretében megszervezett kilencedik Müszaki tudományos ülésszak programfüzetének boritója, fotója, 2008. november 22. (Fotó: $B H Z)$

Az előadások listája időrendi sorrendben: Sikolya László: Az amaránt termesztés és feldolgozás gépesitése Magyarországon; Jármai Károly, Száva János, Dani Péter, Varga Béla: Acélszerkezetek tüzvédelmi tervezése és gyakorlati mérése; Kalmár László, Jármai Károly: Ipari elszivó rendszer hatékonyságának és gazdaságos üzemeltetésének javitása numerikus optimáló algoritmusok alkalmazásával; Pokorádi László: Fuzzy modellek és alkalmazásuk; Tiba Zsolt: Gépészeti modellezés és a környezetbarát üzemeltetés kapcsolata; Bitay Enikő, Kovács Tünde: Lézeres felületkezelés hatásának elemzése a kopásállóságra; Kerekes László: Minőségirányítási rendszerek bevezetése a felsőoktatásban; Imecs Mária, Incze János Jób, Szabó Csaba: Kalickás indukciós motor vektoriális szabályozása kettős mezö-orientációval; ifj. Orbán György: A Biblia mint inspirációs forrás a vallásos épitészetben; Gyenge Csaba, Varga András, Gyenge Zoltán: Környezetbarát technológiák a gépgyártásban; Száva János, Kakucs András, Gálfi Botond: A hengerfejpakolás mechanikai tulajdonságai mint környezetvédelmi tényező; Kakucs András, Száva János, Dani Péter, Gálfi Botond, Jármai Károly: Felhabzó festékek végeselemes modellezése; Pap István: A térmechanizmusok dinamikai kiegyensúlyozásának optimalizálása; Varga Béla: Zink-alumínium ötvözetek eutektoidos átalakulásának dilatométeres vizsgálata; Márton László: Bábos toronyórák a Küküllök középső folyásának vidékéröl; Tamás Levente, Majdik András, Lazea Gheorghe: Állapotbecslési technikák a robot navigációs alkalma- 
zásokban; Szőcs Katalin: A kisérletezö tudományok képjeleiröl. A kör; Baki-Hari ZoltánGábor: Hatékony termékfejlesztés az új évezred kezdetén.

\section{Múszaki tudományos ülésszak, 2009}

A jubileumi évben az Erdélyi Múzeum-Egyesület megalakulásának 150. évfordulóját ünnepeltük, és közelgett a Müszaki Tudományok Szakosztálya megalakulásának 20., a Müszaki tudományos ülésszak elindulásának 10. évfordulója. A tízedik ülésszak háromnyelvü elöadás-kivonatokat tartalmazó programfüzetének előszavában a szakosztályi elnök tollából olvashatjuk a következő gondolatot: ,Lehet-e ünnepnapja a tudománynak? Amennyiben a tudomány müvelése az év minden napjára jellemzö, akkor valóban lehet egy nap, mikor ezen eredményeket összegezzük, megvitatjuk. E hármas ünnep, s az eddig elért eredmények számadásra kötelez, s egyben megújulásra, az új irányok meghatározására, együttmüködések megalapozására késztet”. A programfüzet borítója a 14. képen látható, a teljes tartalma itt olvasható: http://hdl.handle.net/10598/28570.
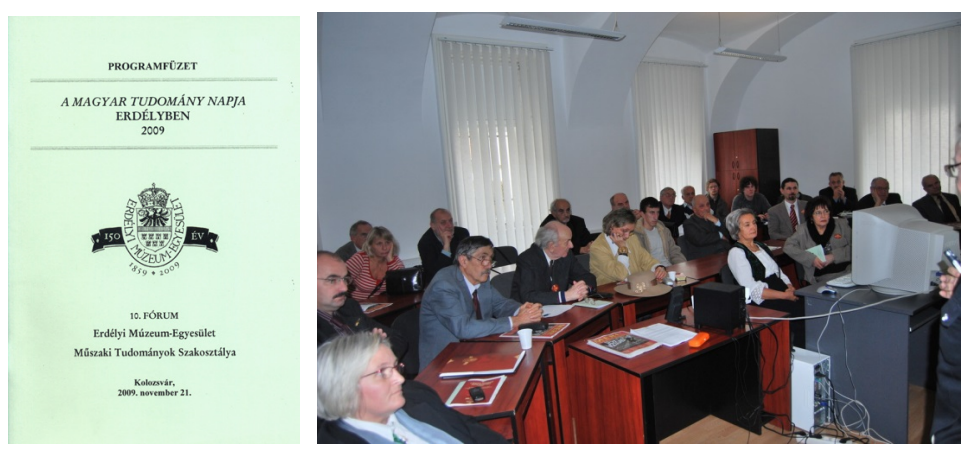

14. kép. A Magyar Tudomány Napja Erdélyben rendezvénysorozat keretében megszervezett tizedik Müszaki tudományos ülésszak programfüzetének boritója, fotója, 2009. november 21. (Fotó: BHZ)

A fórum megnyitó előadását a szakosztályi elnök tartotta a hármas ünnep jegyében, taglalva Müszaki Tudományok Szakosztályának szerepét a magyar müszaki tudományosságban. Ezt követte a tudományos kutatások eredményeit bemutató 16 előadás két részletben.

Az előadások lajstroma sorrendben: Bitay Enikő: Az Erdélyi Múzeum-Egyesület Müszaki Tudományok Szakosztályának szerepe a magyar müszaki tudományosságban; Pokorádi László: A matematikai modellek bizonytalansága; Jármai Károly, Farkas József, Oláh Róbert: Hegesztett szerkezetek optimális méretezésének újabb eredményei; Hajdú Sándor, Lakatos Károly: Bánki Donát nagyszerü alkotása: az 1917-ben szabadalmaztatott kis vízturbina; Varga Béla, Fazakas Éva, Varga Lajos Károly: Dilatométerrel vizsgált amorfkristályos fázisátalakulások alumínium ötvözetekben; Kakucs András, Dani Péter, Jármai Károly, Száva János, Gálfi Botond-Pál: Kísérleti berendezés felhabzó tüzvédelmi bevonatok tanulmányozására; Imecs Mária: Gerjesztő tekercses szinkron generátorok vektoriális 
szabályozása a mezöorientáció elve alapján; Tamás Levente: LIDAR alapú emberfelismerés és -követés mobil robotokkal; Gyenge Csaba, Oláh László: Különleges lefejtömaró edzett hengeres fogaskerekek simitására; Máté Márton, Hollanda Dénes, Papp István: $A$ gömbmozgás néhány kérdéséről; Bitay Enikő, Márton László, Talpas János: Technikatörténeti kutatások Magyargyerömonostor gótikus templománál; Mihalik András: A 155 éves Bezdáni kamarazsilipnek - mint az első magyar, európai betonépítménynek, a világ elsö teljesen betonból épült hajózsilipjének - a viselkedése és diagnosztikája „IN SITU”; Gobesz Ferdinánd-Zsongor, Kopenetz Ludovic: Építés: biztos bizonytalanság; Máthé Aliz Éva, Alexa Pavel, Gobesz Ferdinánd-Zsongor: Néhány korszerü eljárás és eszköz az épületszerkezetek viselkedésének a szabályozásához földrengéskor; Ifj. Orbán György: Városkép a folyók tükrében és a partok hasznosithatósági lehetőségei; Szőcs Katalin: Gyorsuló kihívások az új energia használatánál; Baki-Hari Zoltán-Gábor: Modern termelési metódusok az új RP eljárások segitségével.

\section{Múszaki tudományos ülésszak, 2010}

A tizenegyedik ülésszak 2010. november 20-án hagyományos módon szerveződött. A háromnyelvü rövid összefoglalók, a programfüzet digitális változata itt található: http://hdl.handle.net/10598/28571, a borító a 15. képen látható.

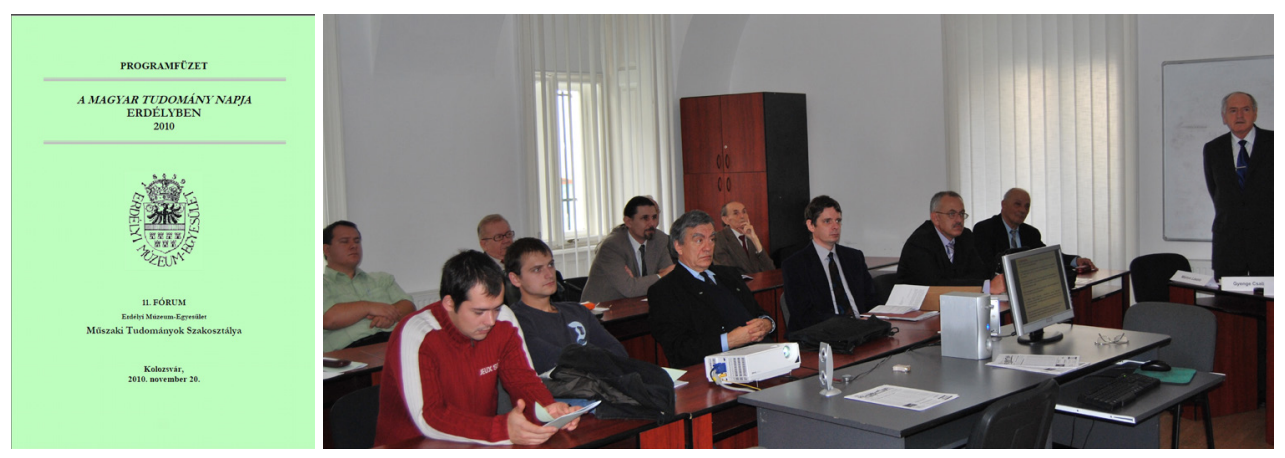

15. kép. A Magyar Tudomány Napja Erdélyben rendezvénysorozat keretében megszervezett tizenegyedik Müszaki tudományos ülésszak programfüzetének boritója, fotója, 2010. november 20. (Fotó: BHZ)

Az előadások lajstroma: Bitay Enikő: Az EME hozzájárulása a müszaki kutatások alapfeltételeinek megteremtéséhez; Pokorádi László: A Monte-Carlo szimuláció szemléltetése és alkalmazása; Dezső Gergely, Szigeti Ferenc, Varga Gyula, Péter László: Szerszámkopás és felületi érdesség vizsgálata környezetbarát megmunkálásoknál; Gyenge Csaba, Frăţilă Domniţa: Gyakorlati kutatások a környezetbarát fogazás területén; Máté Márton, Hollanda Dénes: Arkhimédeszi spirál-vezérgörbéjü hengeres fogaskerekek; Gobesz Ferdinánd-Zsongor, Kopenetz Gh. Ludovic: Számítástechnikai eszközök az építőmérnöki képzésben; Imecs Mária: A térfázor elmélettől a villamos gépek egységes szabalyozási elvéig; 
Vallasek István, Roósz András, Veres Zsolt, Szőke János, Szirovicza Péter, Török Gyula, Káli György: Bizmuttellurid alapú félvezető ötvözetek egykristályainak elöállitása és jellemzése; Varga Béla: Aluminiumolvadékok gáztalanitása; Bitay Enikő, Márton László, Szőcsné Gazda Enikő: Szemelvények a háromszéki vasipar történetéböl (XIX. század); Mihalik András: Szivárgó rendszerü elöregyártott vasbeton elemekböl kivitelezett küszöbgát 25 év alatti viselkedése és diagnosztikája ,in situ” a Sebes-Körös nagyváradi szakaszán; Ifj. Orbán György: Római katolikus egyházi müemlékek és ingatlanok számbavétele és hasznositási lehetőségeinek tanulmányozása a gyulafehérvári föegyházmegyében; BakiHari Zoltán-Gábor: Modern technológiák flexibilis-moduláris szerszámok elöállitására.

\section{Müszaki tudományos ülésszak, 2011}

2011-ben megújult a programfüzet, új borítója (16. kép) érzékelteti, hogy a müszaki ülésszak továbbra is része az EME égisze alatt szervezett A Magyar Tudomány Napja Erdélyben fórumnak. Az előadások háromnyelvü kivonata (magyar, román és angol nyelven) szintén megmaradt, ezzel segítvén a széles körü tájékoztatást. A programfüzet online itt érhető el: http://hdl.handle.net/10598/15441.
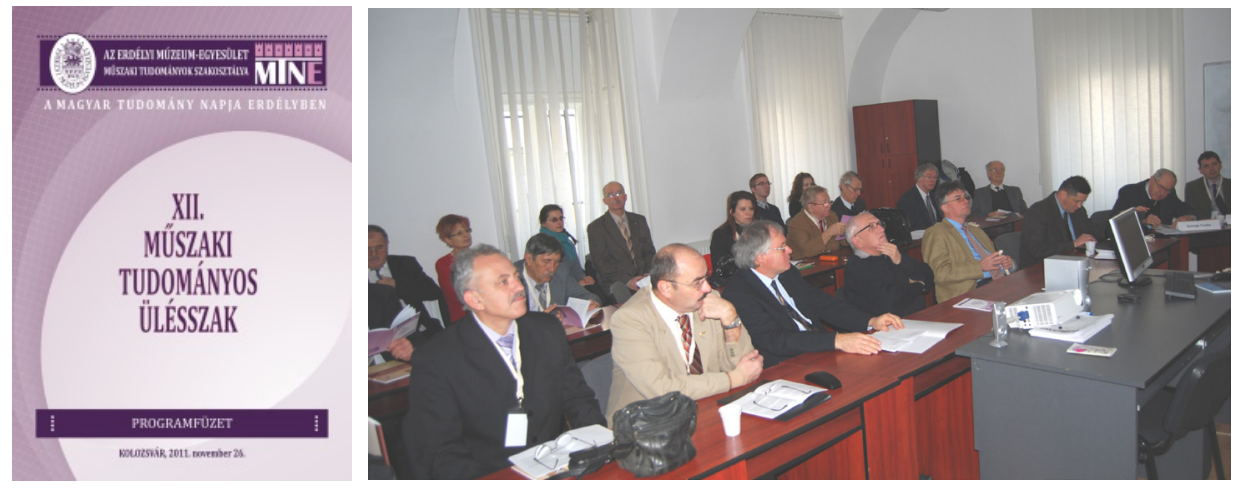

16. kép. A Magyar Tudomány Napja Erdélyben rendezvénysorozat keretében megszervezett XII. Müszaki tudományos ülésszak programfüzetének boritója, fotója, 2011. november 26. (Fotó: TJ)

A fórumon elhangzott előadások lajstroma. Bitay Enikő: A müszaki tudományok gyakorlatorientált fejlesztése - különös tekintettel az oktatásra és a kutatásra; Dudás László: Számítógéppel segitett fogaskerék-fejlesztés; Hollanda Dénes, Máté Márton: Homlokpalást fogazatú alakos tárcsamarók profiltartásának kérdése; Gyenge Csaba, Olah László: Új technológiai eljárás a golyós hajtómüvek gyártására; Jármai Károly, Farkas József, Kovács György, Daróczy László, Barcsák Csaba, Dúl Róbert, Kota László, Oláh Róbert: Szerkezetek és rendszerek optimálása; Tiba Zsolt: Gépészeti tervezés mechatronikai rendszerrel; Kocsis Imre: Alkalmazások bemutatása a müszaki matematika oktatásában: lineáris rendszerek elemzésének eszközei komputeralgebrai rendszerekben; Pokorádi László: Termálvizrendszer bizonytalanságelemzése; Imecs Mária: Kalickás aszinkron motoros 
hajtás vektoriális szabályozása kettős mezöorientációval; Kalmár László, Ralf Hellmann, Régert Tamás, Varga Zoltán: Áramköri panelben nagy teljesítményü led által keltett hövezetési folyamat numerikus szimulációja; Dömötör Ferenc, Lakatos Károly, Szamosi Zoltán: Mezögazdasági hulladékból energia: szalmából készült pellet; Papp Viktória: Agripelletek helyzete Magyarországon; Kolozsváry Zoltán: Hangsúlyváltások a müszaki felülettudomány területén; Papp István: Forgódugattyús motorok fejlesztéséről; KisfaludiBak Zsombor, Gobesz Ferdinánd-Zsongor: Környezetkímélö házak szalmabálából; Bitay Enikő, Márton László, Orbán György, Talpas János: Kolozsvári templomtornyok, harangok, toronyórák. A Szent Mihály-templom és a Ferencesek temploma; Mihálik András: Talajmechanikai és müszaki paraméterek tanulmányozása különbözö támasztószerkezetek struktúrájának a függvényében; Szőcs Katalin: A természettudományok és a mértani formák kapcsolódásai.

\section{Müszaki tudományos ülésszak, 2012}

A XIII. MTÜ változást hozott: a programfüzet meghatározás helyett kivonatfüzet szerepel (17. kép), tartalmazza az előadások háromnyelvű rövid összefoglalóit (magyar, román és angol nyelven). Újítás volt, hogy a kivonatfüzet felkerült az EDA-ba, s a fórum megnyitóján már olvasható volt online módon. „Örömmel jelentem be, hogy a rendezvény megnyitásával egy időben az elöadások tartalmi kivonatai elérhetők az Erdélyi Digitális Adattárban: http://hdl.handle.net/10598/25038.” - olvasható a kivonatfüzet köszöntőjében.
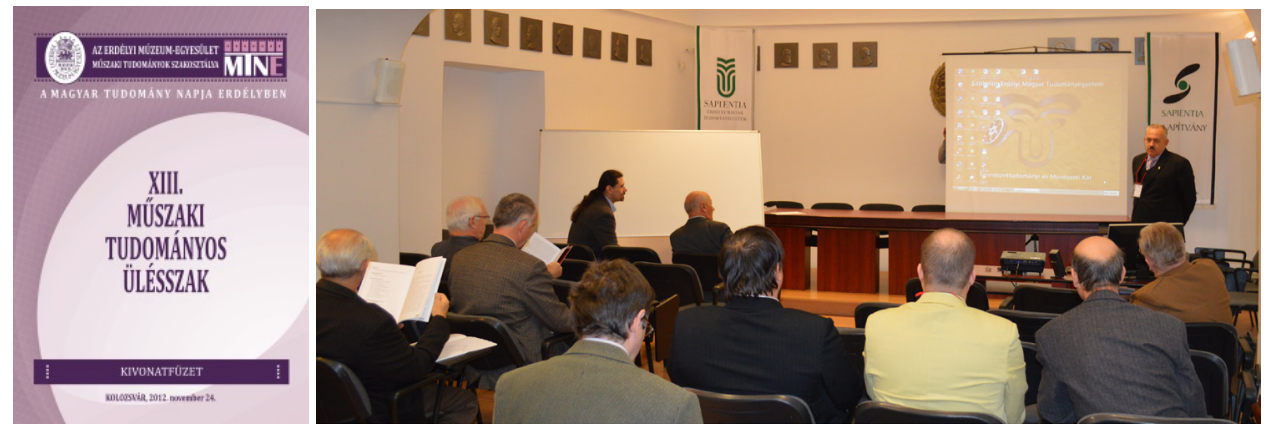

17. kép. A Magyar Tudomány Napja Erdélyben rendezvénysorozat keretében megszervezett XIII. Müszaki tudományos ülésszak programfüzetének boritója, fotója, 2012. november 24. (Fotó: SzJ)

A Magyar Tudomány Napja Erdélyben központi fórumának 2012. évi témája: A felfedezö tudomány 21. század eleji eredményei és távlatai Erdélyben. Ennek keretében Dávid László egyetemi tanárnak, a Sapientia Erdélyi Magyar Tudományegyetem rektorának $A z$ optimális irányítás, egy új innovatív szemlélet a globális felmelegedés gondjainak kezelésére címü plenáris előadását hallhattuk, melyet másnap a müszaki tudományok XIII. ülésszakának előadásai követték. A fórumon - immár hagyományosan - beleláthattunk az EME Mü- 
szaki Szakosztály tudomány- és technikatörténeti szakcsoportjának munkálataiba, egyszersmind megismerhettük egyes intézmények, kutatócsoportok, kutatók aktuális kutatási eredményeit is, s mint mindig, lehetőség nyílt a további szakmai kapcsolatok kialakítására, a jövő irányvonalainak felvázolására a müszaki tudományok terén.

A tanulmányok lajstroma: Bitay Enikő: A magyar müszaki nyelv úttörői, Debreczeni Márton müszótárai; Dezső Gergely, Szigeti Ferenc: Forgácsleválasztás modellezése különbözö homlokszögü forgácsoló ékek esetén; Máté Márton, Hollanda Dénes: A fogaskerék fogfelületén hántolás során kialakuló elméleti érintkezési görbe vizsgálata; Bodzás Sándor, Dudás Illés: Spiroid csiga és tányérkerék virtuális és valós modelljeinek elöállitása; Imecs Mária: Hálózatbarát- és villamosgép-barát teljesítményelektronikai áramirányítók; Bitay Enikő, Márton László, Nagy Tibor, Talpas János: Borsa-völgyi toronyórák; Tamás Levente: Várostérkép készitése 3D-s méréstechnikával; Takács Petra-Renáta, Kisfaludi-Bak Zsombor: Hidrotechnikai alkalmazása egy ismert matematikai függvénynek; Vekov Imre: Betonkenu épitése versenyzés céljából; Orbán György: A Gyulafehérvári Római Katolikus Egyházmegye ingatlanjainak hasznositása Kolozs megye északi részén Mária-zarándokútvonal fejlesztése; Orbán György: Térarányrendszerek eredete Vitruvius átriumos házának zenei értelmezése.

\section{Müszaki tudományos ülésszak, 2013}

A 2013. év újabb áttörést jelentett, régi törekvés valósult meg: sikerült az előadásokat a fórum előtt egy csokorba gyüjteni és cd-n kiadni. Időnk nem volt arra, hogy a szövegeket lektorált formában közölhessük. Ezért 2014-ben - mikor a tanulmányokat már könyv formátumban terveztük kiadni (összegyüjteni s lektorálni) - felmerült fel a gondolat, hogy a XIV. MTÜ tanulmányait is lektoráltassuk, s javított formában kötetben kiadjuk. Erre szolgál a jelen kiadvány.

Mivel a XIV. MTÜ fórumnak volt cd-je, a kivonatfüzet elveszítette jelentőségét, csupán a programot tartalmazó füzetecskét szerkesztettünk (18. kép), mely továbbra is tartalmazta a segítő információkat, online itt olvasható: http://hdl.handle.net/10598/28157.

Ugyancsak újdonság volt ebben az évben, hogy az ülésszak létrehozásában társszervezöként csatlakozott az EME Müszaki Tudományok Szakosztályához a Sapientia EMTE Marosvásárhelyi Müszaki és Humántudományok Kara.

A fórum jelentőségét tovább erősítette az is, hogy ettől az évtől kezdve a rendezvény ünnepélyes keretet biztosított az erdélyi magyar müszaki tudományosságért kifejtett tevékenység elismerésére is. Első ízben adtuk át a Jenei Dezső-emléklapot, amelyet ezúttal Hollanda Dénes és Csibi Vencel professzorok kaptak meg.

A XIV. MTÜ előadásainak lajstroma: Dezső Gergely, Szigeti Ferenc: Forgácsoló megmunkálások szimulációja; Dudás László: Energetikai gépek nem szabályos csavarfelületeinek köszörülése; Dobránszky János, Bitay Enikő, Major László, Nagy Péter: Értágító betétek lézersugaras hegesztése; Máté Márton, Hollanda Dénes: Arkhimédész-féle spirális 
vezérvonalú fogakkal rendelkezö hengeres fogaskerekek foglábfelületének modellezése; Papp István, Tolvaly-Roșca Ferenc: Új módszer a karos mechanizmusok dinamikus kiegyensúlyozására; Imecs Mária: Kettős mezöorientációs szabályozási struktúra mechanikai érzékelö nélküli kalickás indukciós motoros hajtás részére; Gobesz Ferdinánd-Zsongor, Kegyes Csaba: Földrengési szabványok fejlödése és alkalmazása Erdélyben; András József, Kovács József: A mechatronika alkalmazása a bányagépek tervezésében; Sándor Gábor, Szabó György: Az antropogén eredetü anyagok vizsgálata Debrecen talajaiban; Simon Pál: Ütemezési feladatokra alkalmazott genetikus algoritmus keresztezö operátorainak vizsgálata; Kakucs András, Papp István, Tolvaly-Roșca Ferenc, Forgó Zoltán: Bolygódugattyús pneumatikus motor; Bitay Enikő, Márton László, Nagy Tibor Sándor, Talpas János: Kide templomai, toronyórája és harangjai; Vallasek István: A megújuló energiaforrások hasznositásának helyzete Romániában; Orbán György, Talpas János: Zarándoklat, turizmus és építészet Kolozs megyében, a „Mária út” mentén; KovácsCoskun Tünde, Pinke Péter, Bitay Enikő: A szemcseméret és a mechanikai tulajdonságok kapcsolata hegesztett varratoknál.
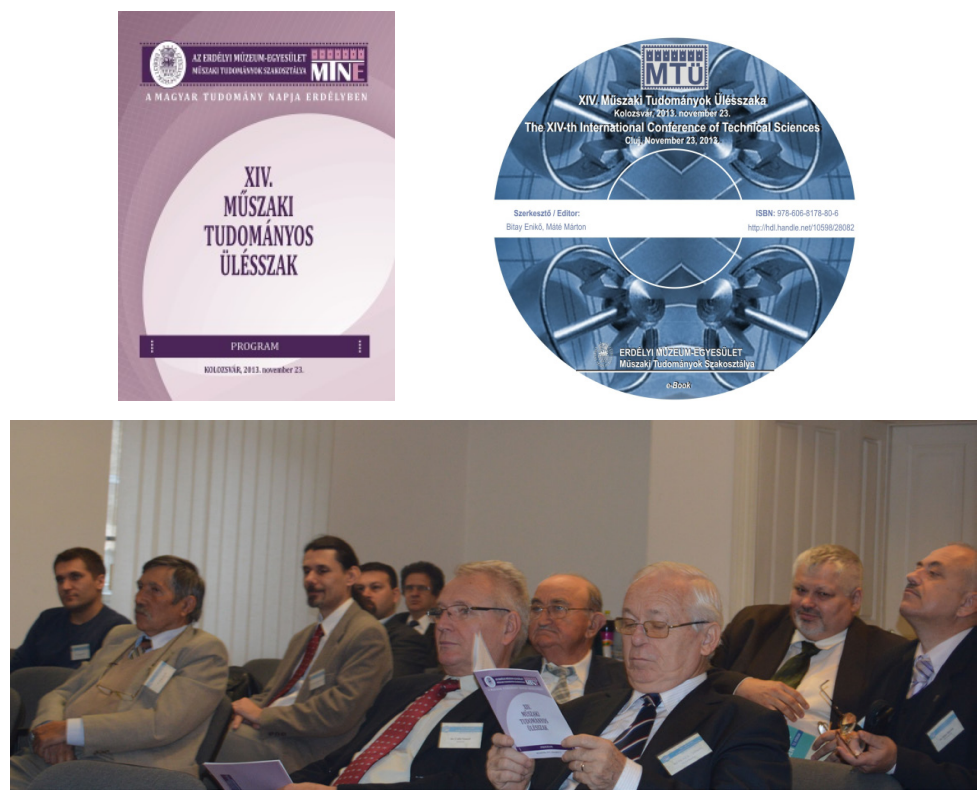

18. kép. A Magyar Tudomány Napja Erdélyben rendezvénysorozat keretében megszervezett XIV. Müszaki tudományos ülésszak programjának boritója, cd-je, fotója, 2013. november 23. (Fotó: TJ)

\section{Múszaki tudományos ülésszak, 2014}

A 2014. évi, XV. MTÜ szervezését eleve, tudatosan úgy indítottuk, hogy a tanulmányok lektorált változatát egy új sorozatban, a Müszaki Tudományos Közleményekben (MTK) 
fogjuk közzétenni. A fórumra, akárcsak az előző évben, csupán program jelent meg kivonatok nélkül (19. kép), amely online itt érhető el: http://hdl.handle.net/10598/28564.

A rendezvény keretében a Jenei Dezső-emléklapot ezúttal Dávid László, a Sapientia Erdélyi Magyar Tudományegyetem rektora vehette át az erdélyi magyar müszaki tudományosságért kifejtett tevékenysége elismeréseként.
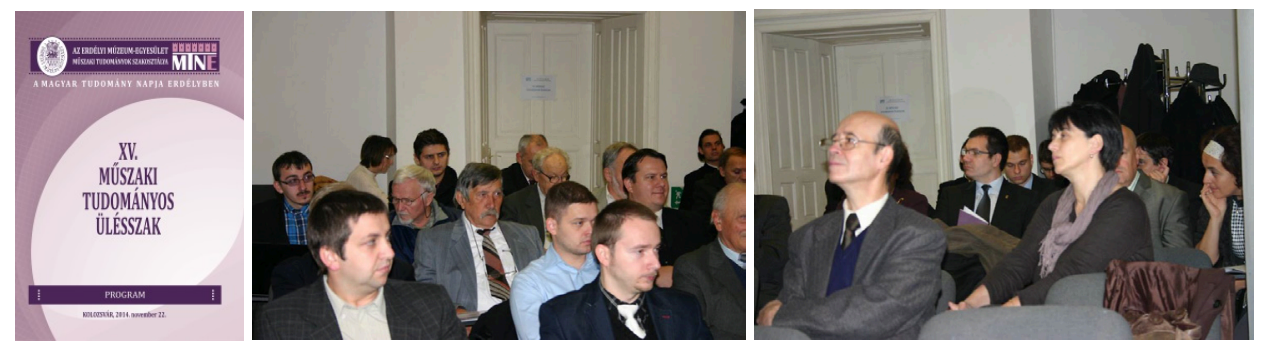

19. kép. A Magyar Tudomány Napja Erdélyben rendezvénysorozat keretében megszervezett XV. Müszaki tudományos ülésszak programjának boritója, fotója, 2014. november 22. (Fotó: TJ)

A megtartott előadások lajstroma, mely egyben az MTK következő, 2. számának a tartalma is: Dezső Gergely, Szigeti Ferenc: Fémforgácsolási folyamatok szimulációja; Dávid László, György Katalin, Kelemen András: Alkalmazott modell-alapú prediktív irányitási algoritmusok összehasonlítása az állapotfüggö Riccati-egyenlet, illetve véges horizontú DLQR algoritmus segitségével; Máté Márton, Hollanda Dénes: Arkhimédész-féle spirális fogirány vonalú hengeres fogaskerekek burkolásának sajátos, a burkolt felületsereg eloszlását jellemző aspektusáról; Márton László, Kocsis Lóránd, Katona Norbert, Szigeti Péter: Biológiai jelfeldolgozás újabb módszerei; Forgó Zoltán, Tolvaly-Roșca Ferenc: Gantry-típusú, párhuzamos hajtású robot modellezése és vizsgálata; Pásztor Judit, Forgó Zoltán: Altalajlazitó munkaeszközének kinematikai és dinamikai vizsgálata; Tolvaly-Roșca Ferenc, Forgó Zoltán: Modern fogaskerék-modellezési eljárások összehasonlitó tanulmánya; Gyenge Csaba: Különleges csigahajtások korszerü technológiája; Popa-Müller Izolda, Papp István, Kakucs András: Tü- és cérnarángató mechanizmus pozíciójának vizsgálata kényszeregyenletek segitségével; Popa-Müller Izolda, Papp István, Kakucs András: Tü- és cérnarángató mechanizmus sebességének vizsgálata kényszeregyenletek segitségével;

Losonczi Lajos: Nem konvencionális megoldások neurobiológiai jelek nem-invaziv méréstechnikájában; Farkas Loránd, Losonczi Lajos: Rendszerfejlesztés beágyazott biológiaiméréstechnikai autonóm kommunikációs hálózatokra; Bakos Levente: Egészségvédelem és társadalmi felelösségvállalás veszélyes ipari rendszerekben; Tihanyi Károly, Törzsök Péter, Dobránszky János, Bitay Enikő: Alumínium-szénszál kompozithuzal mikroszerkezetének vizsgálata; Fekete Albert-Zsombor, Jakab-Farkas László: Parciális nyomások mérésére alkalmas beágyazott rendszer fejlesztése reaktív porlasztóberendezés számára; Kacsó Zoltán, Kelemen András, Imecs Mária: Indukciós gépek rotorfluxusának azonositása csúszómód állapotmegfigyelővel; Szabó Csaba, Imecs Mária, Szőke (Benk) 
Enikő, Incze János Jób: Mechanikai érzékelö nélküli kalickás indukciós motor kettős mezőorientációs szabályozásának implementációja; András József, Kovács József: A Zsilvölgyi szénbányászat a XX. század elején. A korukat meghaladó technológiai újitások; Bitay Enikő, Márton László, Mohácsi Bugárszki Norbert, Angi Norbert: Egy ókori gabonaőrlö szerkezet - a taposómalom újjászületése; Gobesz Ferdinánd-Zsongor, Kopenetz Lajos: A kolozsvári építőmérnöki képzés mai kérdései; Orbán György: A püthagoraszi középarányosok jelentős tulajdonságai és szerepük az épitészetben; Talpas János: Müszaki alkotások megőrzése az idegenforgalom fejlesztésével; Vajdics Dániel, Kovács-Coskun Tünde: A TRIP ponthegesztésének hatása; Vekov Géza, Pokorádi László: Technikai rendszerek állapotleírásának kérdései.

\section{Következtetések}

Az évek során az EME Müszaki Tudományok Szakosztálya a Müszaki tudományos ülésszak megszervezésével hagyományos fórumot teremtett a hazai kutatók munkájának megismertetésére, egyszersmind lehetőséget teremtett külföldi vendégeink számára is intézményük, illetve kutatásaik bemutatására.

Az MTÜ szervesen kötődik a MTNE központi fórumához, ezáltal az MTA A Magyar Tudomány Ünnepe rendezvénysorozatához is.

Az MTÜ tizenöt fórumának áttekintése során világossá vált számunkra, hogy a programfüzeteket visszamenőleg is el kell helyeznünk az EDA-ban, hiszen értékes információkat tartalmaznak. Az egyes előadások tartalmát ugyan nem tudjuk utólag közölni, de kivonatukat s a megvalósult programot közzétehetjük, terjeszthetjük, s érzékeltethetjük ezzel azt is, hogy sok szakmai párbeszédnek, vitának, megoldásnak és szakmai kapcsolatnak volt helye az MTÜ és remélhetőleg ez a továbbiakban is így marad.

Az eddigi tizenöt ülésszak alatt 53 kutatómühely munkáját ismerhettük meg, ebből 30 egyetemi (15 hazai), 8 ipari és 11 kutatási intézmény (6 hazai) volt.

Így az eddigi tizenöt ülésszakon bemutatott 206 előadás révén összesen 362 szerző kutatómunkájába nyerhettünk bepillantást, melyeknek a jelentős része (az utóbbi években ez jellemzö) intézményközi együttmüködés keretében valósult meg.

A Magyar Tudomány Napja alkalmából életre hívott kolozsvári rendezvénysorozat szervesen illeszkedik egyfelől az egyetemes magyar tudományosság ünnepi programjába, másfelől a hagyományos rendezvénysorozat gazdájának, az Erdélyi Múzeum-Egyesületnek törekvéseibe: hidat verni a múlt értékei, a jelen kutatásai, a jövendö eredményei közé, s mindezzel szolgálni a magyar tudományt, az erdélyi magyar közösséget.

\section{Köszönetnyilvánítás}

A szerző köszönetét fejezi ki Kálóczy Katalinnak a szöveggondozásért/olvasószerkesztésért és Szilágy Júlia szakosztályi titkárnak a szakosztályi dokumentumok digitalizálásáért. 


\section{Szakirodalmi hivatkozások}

[1] Benkő Samu: A romániai magyar tudomány helyzete és az Erdélyi Múzeum-Egyesület feladatai. Akaprint, Budapest, 1993. március. 32-33.

[2] Jenei Dezső: Az EME Müszaki Tudományok Szakosztályának feladatai. Kézirat, mely felkérésre készült a szakosztály honlapjának kialakításához, EME-MTSZ, szakosztályi irattár, Kolozsvár, 2000. augusztus 31. http://hdl.handle.net/10598/28573

[3] Bitay Enikő: Az EME Müszaki Tudományok Szakosztályáról röviden. Kézirat, EME-MTSZ, szakosztályi irattár, Kolozsvár, 2009. http://www.eme.ro/muszaki

[4] Tarnóczy Mariann: A tudomány nemzeti funkciója. Korunk, Harmadik folyam XI/3. 2000. március. http://www.hhrf.org/korunk/0003/tartalom.htm.

[5] Tarnóczy Mariann: Akadémiánk és a határon túli magyar kutatás. Magyar Tudomány, 2001/7. http://www.matud.iif.hu/01jul/tarnoczy.html.

[6] Bitay Enikő: Az EME Müszaki Tudományok Szakosztály 10 éves története. Kézirat. Az EME MTSZ irattára, online elérhető az EDA-ban: http://eda.eme.ro/handle/10598/28574)

[7] Csurulya Szidónia: Többszörös évforduló. In: Szabadság Kolozsvári Közéleti Napilap, XII. évfolyam, 279. szám, 2. oldal, 2000. november 28.

[8] Ördög I. Béla: A Magyar Tudomány Napján Müszaki tudományos ülésszak az EME-nél. In: Szabadság Kolozsvári Közéleti Napilap XIII. évfolyam, 258. szám, 1-2. oldal, 2001. november 5.

[9] Ördög I. Béla: A magyar tudomány napja Erdélyben. MTA-EME együttmüködési nyilatkozatot irtak alá. In: Szabadság Kolozsvári Közéleti Napilap XIV. évfolyam, 273. szám, 1., 4. oldal, 2002. november 25. 2002. november 25.

[10] Gaál György: Akadémikusok a Házsongárdban. In: Szabadság Kolozsvári Közéleti Napilap XIV. évfolyam, 272. szám 3. oldal, 2002. november 23.

[11] Lázár Lehel: Az erdélyi és anyaországi kutatók a régiókutatásról értekeztek. A Magyar Tudomány Napja. Kolozsvár. In: Krónika Erdélyi Magyar Közéleti Napilapban, V. évfolyam, 271. szám, 1., 4. oldal, 2003. november 22-23.

[12] Borbély Tamás: A Magyar Tudomány Napja Erdélyben. Konferencia a régiókutatás időszerüségéről. In: Szabadság Kolozsvári Közéleti Napilap XV. évfolyam, 270. szám, 1-2. oldal, 2003. november 22 . 